\title{
Editorial
}

\section{Editorial: Basic Science, Applied Science, and Product Testing}

\author{
Clare M. Rimnac PhD, Seth S. Leopold MD
}

$\checkmark$

rom the first days of Clinical Orthopaedics and Related Research $^{\circledR}$, we have been as interested in publishing the laboratory science that supports the practice of surgery as we are in publishing clinical research [9]. But experimental science varies widely in form and content, and some basic research papers are of much greater importance to our readers - and therefore to us - than others. So what does it mean to say we are interested?

The authors certify that they, or any members of their immediate families, have no commercial associations (eg, consultancies, stock ownership, equity interest, patent/ licensing arrangements, etc) that might pose a conflict of interest in connection with the submitted article.

All ICMJE Conflict of Interest Forms for authors and Clinical Orthopaedics and Related Research ${ }^{\circledR}$ editors and board members are on file with the publication and can be viewed on request.

The opinions expressed are those of the writers, and do not reflect the opinion or policy of $C O R R^{\mathbb{R}}$ or the Association of Bone and Joint Surgeons ${ }^{\circledR}$.

C. M. Rimnac PhD,

S. S. Leopold MD ( $\varangle)$

Clinical Orthopaedics and Related

Research, Philadelphia PA 19103, USA

e-mail: sleopold@clinOrthop.org
In broad terms, the laboratory science papers we see fall into three broad categories: Basic science, applied science, and product development. We publish all three kinds of research, but we consider each genre differently as we review individual papers.

The basic science research that CORR $^{\circledR}$ publishes seeks to address fundamental questions about the biology, chemistry, physics, and engineering related to musculoskeletal functions, illness, disease, or treatments. Basic science research seeks to understand more fully the mechanisms that drive processes (such as osteoarthritis, bone repair, or joint mechanics) without necessarily providing practical applications for the findings made. This often is a high-risk, high-reward venture. Its specific value to doctors and patients may not be recognized for years or decades. The last three Nobel Prizes given in physiology and medicine were awarded for basic-science research the origins of which date back to the "60s, "70s, and '80s [6]. Marshall Urist MD, the second Editor-inChief of this journal, could only have imagined how his foundational work on the ultrastructure of bone-morphogenetic protein [8] would one day be utilized in clinical care, or that it might someday be applied to problems unforeseen in devices yet invented in his day, such as the treatment of osteolysis around cementless arthroplasties [1]. Although we realize that most laboratory scientists working in musculoskeletal disciplines send their true basic science research to journals that focus uniquely on fundamental research, we find basic science to be some of the most exciting research that we see $[7,10]$. While the research itself is fundamental, for it to be of greatest interest to our readership, authors need to explain how it might guide future applied-science efforts, and, at least in a plausibly speculative way, how it may someday influence clinical practice. That is what we mean by "related" in Clinical Orthopaedics and Related Research ${ }^{\circledR}$ [3].

Applied science often builds off of basic science and the two often overlap considerably. For the purposes of this conversation, applied science also includes translational research. Good applied science draws a straight line from the laboratory to the practice of orthopaedic surgery, and so has some immediate clinical relevance. Recent examples in $C O R R^{\circledR}$ might include the studies by Elkins's group [2] and that of Lyons et al. [4], although the latter emphasizes that drawing a sharp 
distinction between basic and applied research sometimes is difficult. By contrast, we are much less interested in studies whose answers can be predicted in advance based on wellestablished fundamental principles. For example, every month, we see and generally reject — "engineering" studies proving that it takes more load to break four sutures than two in some static cadaver tendon repair setting, or testing implants in models whose relevance to in vivo settings is too narrow or is unknown. Ideally, applied science advances the state of the art of a technology, material, or treatment through the use of knowledge obtained from basic science research; this is the "yardstick" we use in the evaluation of applied research studies.

A third kind of laboratory research makes up a large number of papers we review, but a much smaller number of those we publish: Product development studies. Papers that we characterize as product testing typically evaluate only one material or device - or those of one manufacturer — in a laboratory setting. While we recognize the need for such work as part of the regulatory process, other researchers rarely cite these papers since the questions involved often are very narrow, and may involve proprietary materials or designs. Because these papers are of little interest to most readers, they are of less interest to us. And because the audience is narrower, the bar for them to clear in order to be published goes up, in terms of topicality and quality of the work. An imperfect analogy in clinical research is the case report. Although these are rarely read and even more rarely cited, some case reports are important, and we do occasionally publish them. The case reports we find most interesting are those that point to a problem or a complication that was not previously known; so it goes with product testing in the laboratory. Without good controls, it is hard to make an affirmative claim of efficacy or success, but failure is often evident — and well worth sharing.

Some 20 years ago, James McCormick wrote "the neglect of science results in iatrogenic harm and waste of resource" [5]. We agree, and we reaffirm our enthusiasm for "related research," of all sorts.

\section{References}

1. Cook SD, Patron LP, Salkeld SL, Smith KE, Whiting B, Barrack RL. Correlation of computed tomography with histology in the assessment of periprosthetic defect healing. Clin Orthop Relat Res. 2009;467:32133220.

2. Elkins JM, Daniel M, Pedersen DR, Singh B, Yack HJ, Callaghan JJ, Brown TD. Morbid obesity may increase dislocation in total hip patients: a biomechanical analysis. Clin Orthop Relat Res. 2013;471: 971-80.

3. Leopold SS. Editorial - our enthusiasm for "Related Research." Clin Orthop Relat Res. 2013;471:3069-3070.

4. Lyons FG, Gleeson JP, Partap S, Coghlan K, O'Brien FJ. Novel microhydroxyapatite particles in a collagen scaffold: a bioactive bone void filler? Clin Orthop Relat Res. 2014;472:1318-28.

5. McCormick J. The contribution of science to medicine. Perspect Biol Med. 1993;36:315-322.

6. Nobel Foundation. Available at: www.nobelprize.org/nobel_prizes/ medicine/laureates.press.html. Accessed on May 22, 2014.

7. Tannous O, Stall AC, Griffith C, Donaldson CT, Castellani RJ Jr, Pellegrini VD Jr. Heterotopic bone formation about the hip undergoes endochondral ossification: a rabbit model. Clin Orthop Relat Res. 2013;471:1584-92.

8. Urist MR, Strates BS. Bone morphogenetic protein. J Dent Res. 1971;50:1392-1406.

9. Urist MR. Physiologic basis of bonegraft surgery, with special reference to the theory of induction. Clin Orthop Relat Res. 1953;1:207-216.

10. Xiong C, Huang B, Cun Y, Aghdasi BG, Zhou Y. Migration inhibitory factor enhances inflammation via CD74 in cartilage end plates with Modic Type 1 changes on MRI. Clin Orthop Relat Res. 2014;472:1943-54. 